\title{
Inovasi Produk Dan Analisis Kelayakan Usaha Pada Lemari Pakaian Kayu
}

\author{
Aviska Nuravianti*1, Risma Fitriani ${ }^{2}$ \\ 1,2 Program Studi Teknik Industri, Fakultas Teknik, Universitas Singaperbangsa Karawang, Jl. H.S Ronggowaluyo, \\ Karawang, 41361, Indonesia \\ Email: aviska.nuravianti18197@student.unsika.ac.id ${ }^{1}$, risma.fitriani@ft.unsika.ac.id²
}

\begin{abstract}
Abstrak
Perkembangan dunia fashion wanita terutama pada pakaian dan hijab kini berkembang semakin pesat. Hal tersebut mendorong seseorang untuk selalu memenuhi kebutuhan fashion dengan model terbaru. Banyaknya kebutuhan fashion yang dibeli membutuhkan tempat penyimpanan yang tidak hanya sekedar dapat digunakan untuk menyimpan pakaian saja, akan tetapi dapat digunakan untuk menyimpan hijab dan aksesoris lain. Sayangnya, lemari pakaian kayu yang dijual di pasaran masih terbatas pada fungsinya yaitu hanya dapat digunakan untuk menyimpan pakaian. Penelitian ini bertujuan untuk merancang lemari pakaian dan hijab sesuai kebutuhan dan keinginan konsumen serta mengevaluasi peluang usaha tersebut. Untuk membuat desain lemari yang sesuai dengan kebutuhan dan keinginan konsumen digunakan metode Quality Function Deployment (QFD). Hasil penelitian menunjukkan kebutuhan konsumen terhadap lemari pakaian dan hijab yaitu kuat, awet, aman, bahan berkualitas, warna menarik, bentuk unik, multifungsi, praktis, dapat dibongkar, ringan, modern, penyimpanan banyak, tidak mengahabiskan tempat, nyaman, harga terjangkau, dan mudah didapatkan. Evaluasi peluang usaha dilakukan dengan menganalisis tujuh aspek yaitu aspek yuridis, teknis dan teknologi, pasar dan pemasaran, finansial, organisasional, persaingan dan kajian SKB (Amdal). Berdasarkan aspek analisis evaluasi peluang usaha maka usaha lemari pakian dan hijab layak dijalankan.
\end{abstract}

Kata kunci: inovasi, lemari, peluang usaha, produk, solusi

\begin{abstract}
The development of women's fashion, especially in clothing and hijab, is now growing more rapidly. It encourages one to always meet the needs of fashion with the latest models. The many fashion needs purchased require a storage space that can not only be used to store clothes, but can be used to store hijab and other accessories. Unfortunately, wooden wardrobes sold on the market are still limited to its function that can only be used to store clothes. This research aims to design wardrobes and hijabs according to the needs and desires of consumers and evaluate business opportunities. To make a cabinet design that suits the needs and desires of consumers used Quality Function Deployment (QFD) method. The results showed the consumer's need for wardrobe and hijab that is strong, durable, safe, quality materials, attractive colors, unique shapes, multifunctional, practical, can be dismantled, light, modern, storage a lot, not spending space, comfortable, affordable prices, and easy to get. Evaluation of business opportunities is conducted by analyzing seven aspects, namely juridical, technical and technological aspects, market and marketing, financial, organizational, competition and SKB (Amdal) studies. Based on the aspect of the evaluation of business opportunities, the business of pakian cabinets and hijabs is worth running.
\end{abstract}

Keywords: innovation, cupboard, business opportunities, product, solutions

\section{Pendahuluan}

Dunia fashion saat ini mengalami perkembangan yang cukup pesat. Hal tersebut dapat dilihat dari berkembangnya model busana yang semakin beragam. Fashion menjadi salah satu hal penting yang menunjang penampilan seseorang. Model-model busana terbaru menjadi daya tarik konsumen untuk membeli dan memengoleksi busana yang diinginkan. Fashion tidak hanya mencakup busana saja akan tetapi barang-barang fungsionalis lain yang dapat menunjang penampilan seperti kerudung dan aksesories seperti jam tangan, kalung, bros, kacamata, gelang. Penampilan dengan busana, dan hijab yang serasi akan berpengaruh pada penampilan seseorang. Sehingga busana dan hijab menjadi suatu hal yang banyak dicari konsumen untuk menunjang penampilannya. Banyaknya busana dan hijab yang dikoleksi membutuhkan lemari yang memiliki kapasitas cukup besar untuk menyimpan pakaian dan hijab yang dimiliki agar tetap bersih dan rapih ketika akan digunakan. Lemari yang saat ini banyak dijual di pasaran adalah lemari yang hanya dapat digunakan untuk menyimpan pakaian saja. Untuk menyimpan busana, hijab serta aksesoris lain diperlukan lemari multifungsi yang berguna untuk mempermudah dalam menentukan serta mencocokan pakaian, busana serta aksesoris yang ingin digunakan pada satu lemari. Sehinggat diperlukan

${ }^{*}$ Penulis korespondensi 
perancangan lemari pakaian dan hijab yang sesuai dengan kebutuhan dan keinginan konsumen. Inovasi produk adalah cara yang sistematis mengenai pengembangan produk yang dapat diterima dan sesuai dengan kebutuhan konsumen (Shofa \& Iman, 2020)

Studi kelayakan usaha merupakan suatu aktivitas mengevaluasi, menganalisis dan menilai kelayakan atau tidaknya suatu usaha untuk dijalankan. Secara umum, tujuan dilakukan studi kelayakan khususnya bagi investor adalah untuk menghindari investasi atau penanaman modal yang besar untuk suatu usaha atau kegiatan usaha yang hasilnya tidak menguntungkan (Afiyah, Saifi \& Dwiatmanto, 2015)

Berdasarkan latar belakang tersebut, maka pada penelitian ini akan dibuat desain lemari pakaian dan hijab yang sesuai dengan kebutuhan dan keinginan konsumen. Perancangan produk lemari multifungsi memperhatikan berbagai aspek studi kelayakan usaha dalam menciptakan produk yang sesuai dengan kebutuhan dan keinginan konsumen. Untuk mengetahui kebutuhan dan keinginan konsumen terhadap produk lemari pakaian dan hijab digunakan metode Quality Function Deployment (QFD). Metode QFD adalah salah satu metode yang berguna dalam merancang suatu produk sesuai dengan keinginan dari konsumen yang dilihat berdasarkan aspek kualitas (Anggraeni, Desrianty, \& Yuniar, 2013). QFD berguna untuk dapat meningkatkan persaingan dengan perbaikan kualitas dan produktifitas yang berkesinambungan dengan meningkatkaan keandalan pada produk, meningkatkan kualitas produk, meningkatkan kepuasan terhadap konsumen, mempersingkat time to market, memengurangi biaya perancangan, meningkatkan komunikasi, meningkatkan produktivitas dan meningkatkan keuntungan yang diperoleh perusahaan (Trenggonowati, 2013). Prioritas kebutuhan dan keinginan dari konsumen terhadap produk lemari pakaian dan hijab dapat diketahui melalui QFD.

Ketika akan membangun sebuah usaha diperlukaan sebuah perencanaan yang baik dengan mengkaji beberapa aspek dalam mengevaluasi peluang usaha. Berbagai aspek yang digunakan dalam mengevaluasi peluang usaha adalah aspek yuridis, aspek teknis dan teknologis, aspek pasar dan pemasaran, aspek financial, aspek organsasi, aspek persaingan, dan aspek kajian SKB (Amdal). Studi kelayakan binis menjadi langkah yang penting harus dilakukan ketika akan memulai usaha atau mengembangkan usaha agar menjadi lebih maju. Selain itu studi kelayakan usaha menjadi alat yang dapat digunakan untuk bahan pertimbangan dalam mengambil keputusan untuk menerima atau menolak usulan investasi (Kristian \& Indrawan, 2019). Studi kelayakan usaha merupakan suatu ide usaha yang memberi manfaat besar bagi stakeholder dan sedikit erugian sehingga ide usaha layak atau tidak untuk dijalankan (Faradiba \& Musmulyadi, 2020) . Pada pengembangan produk lemari pakaian kayu menjadi lemari pakaian dan hijab dibuat evaluasi untuk menjalankan usaha lemari agar usaha dapat berjalan dengan baik. Aspek yang dikaji dalam evaluasi peluang usaha lemari pakaian dan hijab meliputi tujuh aspek yaitu aspek yuridis, aspek teknis dan teknologis, aspek pasar dan pemasaran, aspek financial dengan menganalisis kelayakan investasi, aspek organisasional, aspek persaingan, dan aspek kajian SKB (Amdal). Tujuan penelitian ini yaitu merencanakan studi kelayakan usaha lemari multifungsi berdasarkan kedua metode diatas.

\section{Metode Penelitian}

Penelitian yang dilakukan menggunakan metode Quality Function Deployment (QFD) untuk mengetahui kebutuhan dan keinginan pelanggan terhadap lemari multifungsi. Selain itu untuk mengetahui layak atau tidaknya usaha lemari multifungsi ini dilakukan analisis terhadap peluang usaha berdasarkan tujuh aspek.

\subsection{QFD}

Metode QFD yang digunakan dalam melakukan penelitian ini terdiri tasa beberapa tahap sebagai berikut:

a. Pembuatan kuisioner

Penelitian dilakukan dengan pengumpulan data primer melalui kuisioner yang dibuat menggunakan Google Form. Pengumpulan data dilakukan dengan mengajukan pertanyaan kepada 30 mahasiswa yang berdomisili di kabupaten Karawang dengan rentang usia 17 tahun sampai 21 tahun. Alasan pemilihan kota Karawang dikarenakan kota tersebut akan menjadi target pasar penjualan produk lemari multifungsi. Dalam pembuatan QFD dilakukan dengan membandingkan antara produk yang akan dirancang dengan produk pesaing. Penelitian dilakukan dalam dua tahap penyebaran kuisioner, kuisioner pertama berupa kuisioner terbuka bertujuan untuk mengetahui kebutuhan dan keinginan konsumen terhadap produk lemari pakaian dan hijab. Jumlah responden kuisioner ditentukan dengan menggunakakn rumus slovin dengan jumlah populasi 41 orang dan tingkat ketelitian $10 \%$ seperti berikut:

$\mathrm{n}=\frac{41}{1+41(0,1)^{2}}=29,07=30$

Hasil kuisioner pertama berupa kebutuhan dan keinginan konsumen terhadap perancangan produk lemari mulltifungsi seperti kuat, awet, aman, bahan berkualitas, warna menarik, bentuk unik, multifungsi, praktis, dapat dibongkar, ringan, modern, penyimpanan banyak, tidak mengahabiskan tempat, nyaman, harga terjangkau, dan mudah didapatkan.

Kuisioner kedua bertujuan untuk mengetahui tingkat kepentingan terhadap aspek kebutuhan dan keinginan konsumen dan menilai produk pesaing 
mengenai tingkat kepentingan terhadap kebutuhan dan keinginan konsumen. Penilalian dilakukan dengan menggunakan skala linier dengan skala 1 hingga 5 dimana skala 1 yaitu sangat tidak penting hingga skala 5 yaitu sangat penting. Hasil kuisioner kedua berupa penilaian tingkat kepentingan konsumen terhadap aspek kebutuhan dan keinginan terhadap perancangan produk multifungsi dan produk pesaing.

b. Metode pohon objektif

Metode ini dilakukan dengan menguraikan kebutuhan konsumen yang telah diperoleh dari hasil kuisioner terbuka sebelumnya, dengan menempatkan faktor yang lebih sempit sebagai bagian dari faktor yang lebih luas. Kemudian lakukan pendataan objektif tingkat atas dan tingkat bawah berdasarkan pengelompokkan secara umum menurut tujuan hirarki. Setelah itu, membuat diagram pohon objektif yang menggambarkan hubungan secara hirarki dan keterkaitan untuk objektif sebagai level atas dan sub objek tif sebagai level bawah. Gambar diagram pohon objektif dapat dilihat pada gambar dibawah ini.

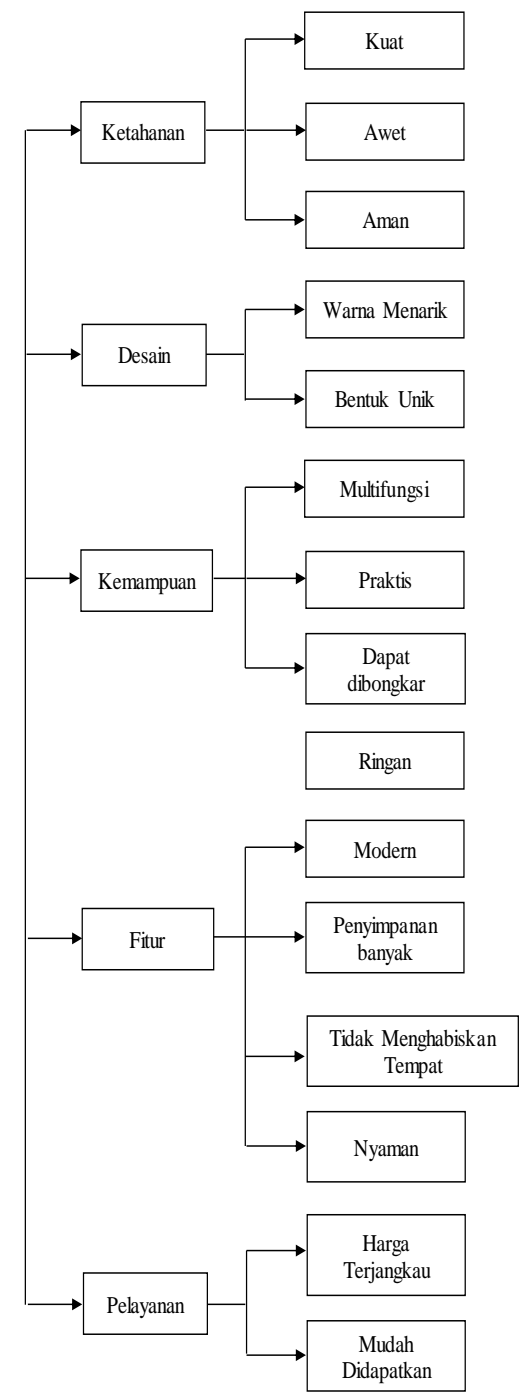

Gambar 1. Diagram Pohon Objektif c. Penentuan Karakteristik Teknik

Mengelompokkan kebutuhan dan keinginna konsumen kedalam istilah atribut produk atau karakteristik teknik yang dibutuhkan untuk perancangan. Hasil karakteristik tersebut adalah jenis bahan, keindahan desain, biaya produksi, model produk, ergonomis, pemasaran.

d. Pengolahan Data

1) Hasil kuisioner kebutuhan dan keinginan konsumen terhadap rancangan produk lemari multifungsi akan diuji validitas menggunakan validitas konstruk dengan menghitung korelasi dari setiap pernyataan dengan skor total yang diperoleh dengan menggunakan rumus teknik korelasi produk, yaitu:

$$
r=\frac{\mathrm{N}\left(\sum \mathrm{XY}\right)-\left(\sum \mathrm{X}\right)\left(\sum \mathrm{Y}\right)}{\sqrt{\left[\mathrm{N}\left(\Sigma \mathrm{X}^{2}\right)-\left(\sum \mathrm{X}^{2}\right)\right] \cdot\left[\mathrm{N}\left(\Sigma \mathrm{Y}^{2}\right)-\left(\sum \mathrm{Y}^{2}\right)\right]}}
$$

2) Setelah semua data dinyatakan valid, kemudian dilakukan uji reliabilitas dengan menggunakan software SPSS 12.0. Nilai koefisien atau alpha cronbach verada diantara 0 sampai 1. Apabila nilai koefisien reliabilitas atau alpha cronbach $\geq 0,7$ menunjukkan bahwa alat ukur yang digunakan sudah handal.

3) Untuk memastikan bahwa data yang diperoleh telah cukup, dilakukan uji kecukupan data dengan menentukan jumlah sampel mínimum (n) yang dapat diolah. Uji kecukupan data dihitung dengan menggunakan rumus Bernaulli (Walpole), yaitu:

$\mathrm{N} \geq \mathrm{n}$,

$\mathrm{N} \geq \frac{Z_{\left(\frac{a}{2}\right)}^{2} \times p \times q}{e^{2}}$

4) Perhitungan nilai kepentingan konsumen dilakukan untuk mengetahui tingkat kepentingan penilaian konsumen yang dilakukan menggunakan metode statistik menggunakan perhitungan distribusi frekuensi dengan mengurutkan nilai 1 sampai dengan 5 . Hal utama yang perlu dilakukan adalah menghitung jumlah pemilihan setiap ítem keinginan konsumen serta karakteristik teknik rancangan lemari multifungsi dan produk lemari pesaing untuk memperoleh volume pemilihan dari setiap ítem. Selanjutnya menghitung interval kelas (i) menggunakan rumus:

$\mathrm{I}=\frac{\text { Volume terbesar-Volume terkecil }}{5}$

5) Menghitung penilaian kualitas produk terhadap pesaing sebagai persyaratan kebutuhan dan keinginan konsumen yang dihitung menggunakan rumus sebagai berikut:

$\bar{\chi}=\frac{\text { Jumlah nilai dari responden }}{\text { Jumlah responden }}$ 
e. Mengembangakn matriks perancangan produk.

1) Menggambar suatu matriks kebutuhan dan keinginan konsumen yang berlawanan dengan karakteristik teknik. Atribut produk membentuk bari matriks dan karakteristik teknik membentuk kolom matriks. Setiap sel menunjukkan hubungan potensial diantara karakteristik teknik dengan kebutuhan konsumen.

2) Mengidentifikasi hubungan diantara kebutuhan dan keinginan konsumen yang berlawanan dengan karakteristik teknik. Penjelasan mengenai tingkat kekuatan hubungan antara kebutuhan konsumen dengan karakteristik teknik dilakukan dengan memberi simbol pada sel-sel matriks. Penilaian hubungan dapat dilakukan menggunakna angka 9 (untuk hubungan samgat kuat), 3 (hubungan kuat), 1 (hubungan lemah) atau dapat juga dilakukan dengan memberi simbol-simbol. Simbol kuat menunjukkan bahwa variabel tidak dapat diwujudkan tanpa adanya karakteristik komponen yang terkait. Hubungan sedang menunjukkan bahwa variabel masih dapat diwujudkan tanopa adanya karakteristik komponen yang terkait, namun hasil yang diperoleh tidak akan maksimal. Hubungan lemah menunjukkan bahwa variabel tidak bergantung dengan karakteristik komponen tersebut.

3) Mengidentifikasi interaksi antara karakteristik teknik yang dilakukan untuk menunjukkan deskripsi secara teknis mana saja yang saling mendukung dan yang saling bertentangan. Simbol yang digunakan untuk menentukan hubungan interaksi antar karakteristik teknik yaitu lingkaran hitam yang menunjukkan hubungan positif kuat dengan nilai +9 , lingkaran putih menunjukkan hubungan positif dengan nilai +3 , kotak putih menunjukkan hubungan negatif dengan nilai 3 dan kotak hitam menunjukkan hubungan negatif kuat dengan nilai -9 .

f. Penentuan target

Penentuan nilai target untuk produk lemari tidak selalu berada diatas nilai kualitas dari produk pesaing, karena disesuaikan dengan efisiensi dan keefektifan dari usaha itu sendiri. Owner usaha lemari menentukan apakah ingin tetap produknya tidak berubah, meningkatkan produk atau membuat produk yang lebih baik dari pesaing. Nilai yang diguakan adalah 1 yaitu paling buruk, 2 yaitu buruk, 3 yaitu cukup baik, 4 yaitu baik, dan 5 paling baik. g. Pengembangan prioritas persyaratan pelanggan

Pengembangan persayaratan pelanggan dilakukan oleh owner usaha lemari dengan menentukan faktor skala, poin penjualan dan bobot absolut.

1) Faktor skala

Faktor skala merupakan perbandingan antara nilai target terhadap tingkat produk yang diberikan dalam penilaian pesaing melalui pelanggan. Semakin tinggi jumlahnya maka upaya lebih diperlukan. Pertimbangan penting dalam hal ini yaitu tingkat dimana produk sekarang dan apa tingkatan targetnya dan memutuskan apakah perbedaannya dalam alasan.

Faktor skala $=\frac{\text { Nilai target }}{\text { penilaian } \text { kualitas produk }}$

2) Poin penjualan

Poin penjulalan menunjukkan seberapa baik ssuatu persyaratan pelanggan akan terjual. Tujuannya adalah mempromosikan persyaratan terbaik pelanggan dan beberapa persayaratan pelanggan lainnya yang akan membantu dalam penjualan produk. Poin penjualan bersisi informasi yang mengkarakteristikan kemampuan dalam menjual produk berdasarkan sejauh mana kebutuhan pelanggan dapat terpenuhi. Nilai poin penjualan yang digunakan adalah 1,0 untuk penjualan rendah, 2,0 untuk penjualan sedang dan 3,0 untuk penjualan tinggi.

3) Bobot absolut

Bobot absolut bobot absolut menunjukkan kepentingan secara kesekuruhan dari setiap kebutuhan pelanggan. Bobot absolut dihitung dengan mengalikan kepentingan terhadap pelanggan, faktor skala dan poin penjualan.

h. Kembangakn prioritas deskripsi secara teknik

1) Bobot absolut teknis

Bobot absolut teknis diperoleh dengan menjumlahkan hasil perkalian antara bobot yang dutentukan pada matriks hubungan dengan vektor kolom dari kepentingan terhadap pelanggan pada persyaratan pelanggan. Bobot absolut teknis dapat dicari menggunakan rumus yaitu:

$a_{j}=\sum_{i=1}^{n} r_{i j} c_{i}$

2) Bobot relatif

Bobot relatif mendeskripsikan secara teknis dengan cara mengganti tingkat kepentingan persyartan pelanggan dengan bobot absolut pada persyaratan pelanggan adalah:

$b_{j}=\sum_{i=1}^{n} r_{i j} d_{i}$ 
i. Matriks perancangan produk

Fokus dari QFD yaitu adalah rumah kualitas atau HOQ yang merupakan fase pertama dari QFD. Bentuk matrks QFD dapat dilihat pada gambar 2 berikut.

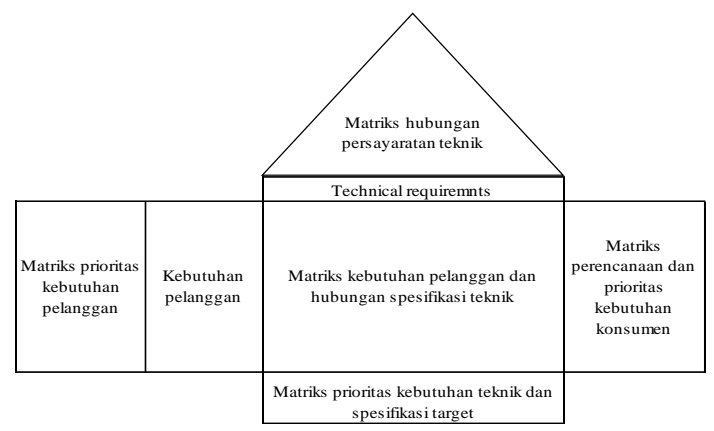

Gambar 2. Quality Function Deployment (QFD)

\subsection{Aspek Kajian Evaluasi Peluang Usaha}

Studi kelayakan usaha terdiri dari 3 aspek yaitu aspek pasar yang terdiri pasar konsumen dan dan produsen, aspek internal perusahaan yang terdiri dari pemasaran, teknik dan teknologi, manajemen, sumber daya manusia dan keuangan, dan aspek aspek lingkungan terdiri dari politik, ekonomi dan sosial, lingkungan industri, yuridis (legal) dan lingkungan hidup (Gunawan, 2018). Untuk mengetahui kelayakan usaha lemari pakian dan hijab dilakukan pengkajian terjadap tujuh aspek sebagai berikut:

\section{a. Aspek yuridis}

Aspek yuridis meiputi penelitian kelengkapan, kesempurnaan, dan keaslian dokumen-dokumen. Penilaian ini meliputi badan hukum, perusahaan (perseorangan, perusahaan negara atau daerah, PT, firma, CV, koperasi, yayasan), izin-izin yang dimiliki, sertifikat tanah dan dokumen pendukung lain.

b. Aspek teknis dan teknologi

Hal-hal yang perlu diperhatikan dalam aspek ini yaitu lahan, peralatan dan mesin produksi yang dibutuhkan, banyaknya tenaga kerja yang diperlukan, bahan untuk produksi, proses pengadaan dan cara pembayaran, layout mesin dan peralatan, proses produksi lemari, atribut produk seperti desain, fleksibilitas dan keamanan.

c. Aspek pasar

Pada aspek ini dilakukan análisis terhadap keadaan pasar pada saat ini yang meliputi perkembangan terhadap permintaan dan peawaran produk, perkembangan harga, jumlah pelanggan potensial dan kebijakan pemerintah yang berhubungan dengan usaha, karakteristik konsumen yang dituju dengan menganalisis karakterisktik demografis seperti usia, tempat tinggal dan lainlain. Memperkirakan estimasi pemasaran di masa yang akan datang seperti estimasi perubahan terhadap permintaan dan penawaran dan perubahan selera konsumen. Estimasi potensi pasar seperti menghitung potensi penerimaan berdasarkan pembelanjaan yang dilakukan oleh pelanggan.

d. Aspek finansial

Hal-hal yang perlu diperhatikan dalam aspek finansial meliputi biaya investasi dan modal kerja, struktur fiannsial dan sumber modal, jadwal pembayaran hutang, estiasi penjualan, estimasi biaya produksi, cash flow dan cost capital, proyeksi neraca dan rugi laba dan kriteria investasi.

e. Aspek organisasional

Pada aspek ini dilakukan análisis terhadap jumlah dan kualifikasi sumber daya manusia yang diperlukan dalam menjalankan usaha.

f. Aspek persaingan

Aspek ini menganalisis mengenai jumlah pesaing dan kekuatan serta kelemahan peasing seperti pangsa pasar, keunikan produk jaringan distribusi dan promosi teknologi produksi.

\section{Hasil dan Pembahasan}

Setelah dilakukan perhitungan berdasarkan data yang telah diperoleh hasil dan pembahasan dari penelitian ini adalah sebagai berikut:

\subsection{QFD}

QFD adalah suatu metode yang berguna untuk memperbaiki atau mengembangkan produk agar sesuai dengan kebutuhan dan keinginan konumen. Hal ini sesuai dengan yang dijelaskan oleh trenggonowati (2017) yang menyatakan bahwa metode QFD berguna untuk dapat meningkatkan persaingan dengan perbaikan kualitas dan produktifitas yang berkesinambungan dengan meningkatkaan keandalan pada produk, meningkatkan kualitas produk, meningkatkan kepuasan terhadap konsumen, mempersingkat time to market, memengurangi biaya perancangan, meningkatkan komunikasi, meningkatkan produktivitas dan meningkatkan keuntungan yang diperoleh. Langkahlangkah dalam membuat QFD pada penelitian ini adalah sebagai berikut:

a. Menentukan kebutuhan dan keinginan pelanggan

Berdasarkan hasil kuisioner diperoleh kebutuhan dan keinginan konsumen terhadap produk lemari pakaian dan hijab sebanyak 16 atribut. Atribut-atribut tersebut yaitu modern, multifungsi, awet, kuat, aman, praktis, bentuk unik, tidak menghabiskan tempat, murah, bahan berkualitas, mudah didapatkan, penyimpanan banyak, nyaman, ringan, warna menarik dan dapat dibongkar.

b. Penentuan karakteristik-karakteristik teknik Setiap kebutuhan dan keinginan pelanggan terhadap produk lemari multifungsi didefinisikan kedalam karakteristik teknik sehingga produk yang dikembangkan dapat dirancang. 
Tabel 1. Karakteristik teknik

\begin{tabular}{ccc}
\hline No & $\begin{array}{c}\text { Karakteristik } \\
\text { Teknik }\end{array}$ & $\begin{array}{c}\text { Komponen } \\
\text { karakteristik }\end{array}$ \\
\hline 1 & Jenis bahan & $\begin{array}{c}\text { Kuat, bahan } \\
\text { berkualitas, awet, }\end{array}$ \\
\hline 2 & Keindahan desain & $\begin{array}{c}\text { Warna menarik, } \\
\text { bentuk unik }\end{array}$ \\
\hline 3 & Biaya produksi & Harga terjangkau \\
\hline 4 & Model produk & $\begin{array}{c}\text { Multifungsi, praktis, } \\
\text { penyimapanan banyak }\end{array}$ \\
\hline 5 & Ergonomis & Nyaman \\
\hline 6 & Pemasaran & Mudah didapatkan \\
\hline
\end{tabular}

c. Membangun hubungan atara kebutuhan pelanggan dengan karakteristik teknik

1) Komponen karakteristik kuat, bahan berkualitas dan awet dapat diterjemahkan kedalam karakteristik teknik dengan jenis bahan

2) Warna unik dan bentuk yang unik dapat dapat diterjemahkan dengan keindahan desain

3) Harga terjangkau dapat diterjemahkan dengan biaya produksi

4) Multifungsi, praktis dan penyimpanan banyak dapat diterjemahkan dengan model produk

5) Nyaman dapat diterjemahkan dengan ergonomis

6) Mudah didapatkan dapat diterjemahkan dengan pemasaran

d. Identifikasi hubungan antara kebutuhan dan keinginan konsumen berlawanan karakteristik teknik

Tingkat kekuatan hubungan antara kebutuhan konsumen dan karakteristik teknik dengan mencatat pada sel-sel matriks. Penilaian hubungan dilakukan dengan menggunakan angka 9 (ubtuk hubungan sangat kuat), 3 (hubungan kuat), 1 (hubungan lemah), atau dapat juga menggunakan simbolsimbol. Simbol kuat menandakan bahwa variabel tidak dapat direakisasikan tanpa adanya karakteristik komponen yang terkait. Hubungan sedang menunjukkan variabel masih dapat direalisasikan tanpa adanya karakteristik komponen yang terkait akan tetapi hasil yang didapatkan tidak dapat maksimal. Hubungan lemah menunjukkan variabel tidak tergantung pada karakteristik komponen tersebut.

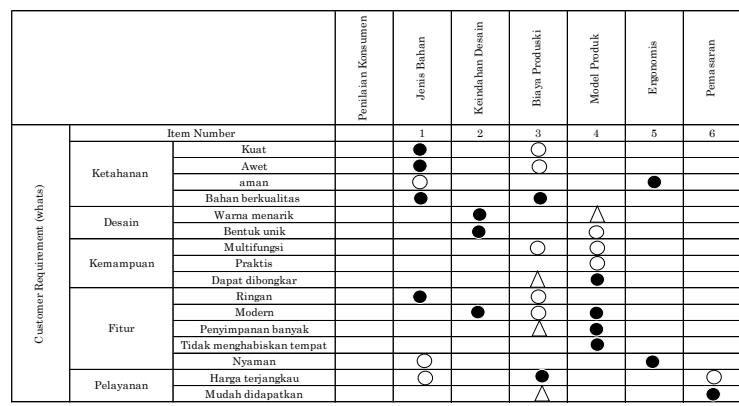

Gambar 3. Hubungan antara kebutuhan dan karakteristik teknik e. Identifikasi hubungan antara karakteristik teknik

Mengidentifikasi hubungan setiap karakteristik teknik untuk menunjukkan deskripsi secara teknis yang saling mendukung dan yang saling bertentangan. Matriks korelasi berbentuk tabel segitiga yang digunakan untuk menunjukkan hubungan antara karakteristik teknis yang satu dengan karakteristik teknis yang lain dengan menggunakan simbol. Hubungan setiap karakteristik teknik merupakan bagian dari atap QFD yang menunjukkan keterkaitan setiap karakteristik teknik. Hubungan antar setiap karakteristik teknik seperti pada gambar 3 berikut.

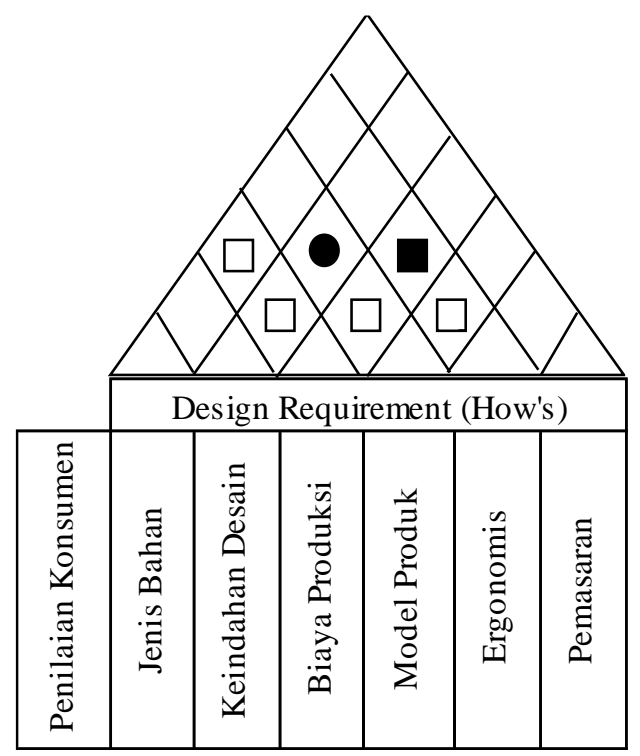

Gambar 4. Hubungan antar karakteristik teknik

Simbol-simbol yang digunakan untuk menunjukkan hubungan setiap karakteristik teknis yaitu simbol lingkaran hitam memiliki nilai +9 menunjukkan hubungan positif kuat, simbol lingkaran putih memiliki nilai +3 menunjukkan hubungan positif, simbol kotak putuh memiliki nilai -3 menunjukkan hubungan negatif dan simbol kotak hitam memiliki nilai -9 menunjukkan hubungan negatif kuat.

f. Pengembangan prioritas persyaratan pelanggan.

Pengembangan persyaratan pelanggan dilakukan dengan menentukan faktor skala, poin penjualan dan bobot absolut. Faktor skala, poin penjualan dan bobot absolut pada perancangan produk lemari multifungsi seperti pada tabel 2 berikut. 
Tabel 2. Pengembangan Prioritas Persyaratan Pelanggan

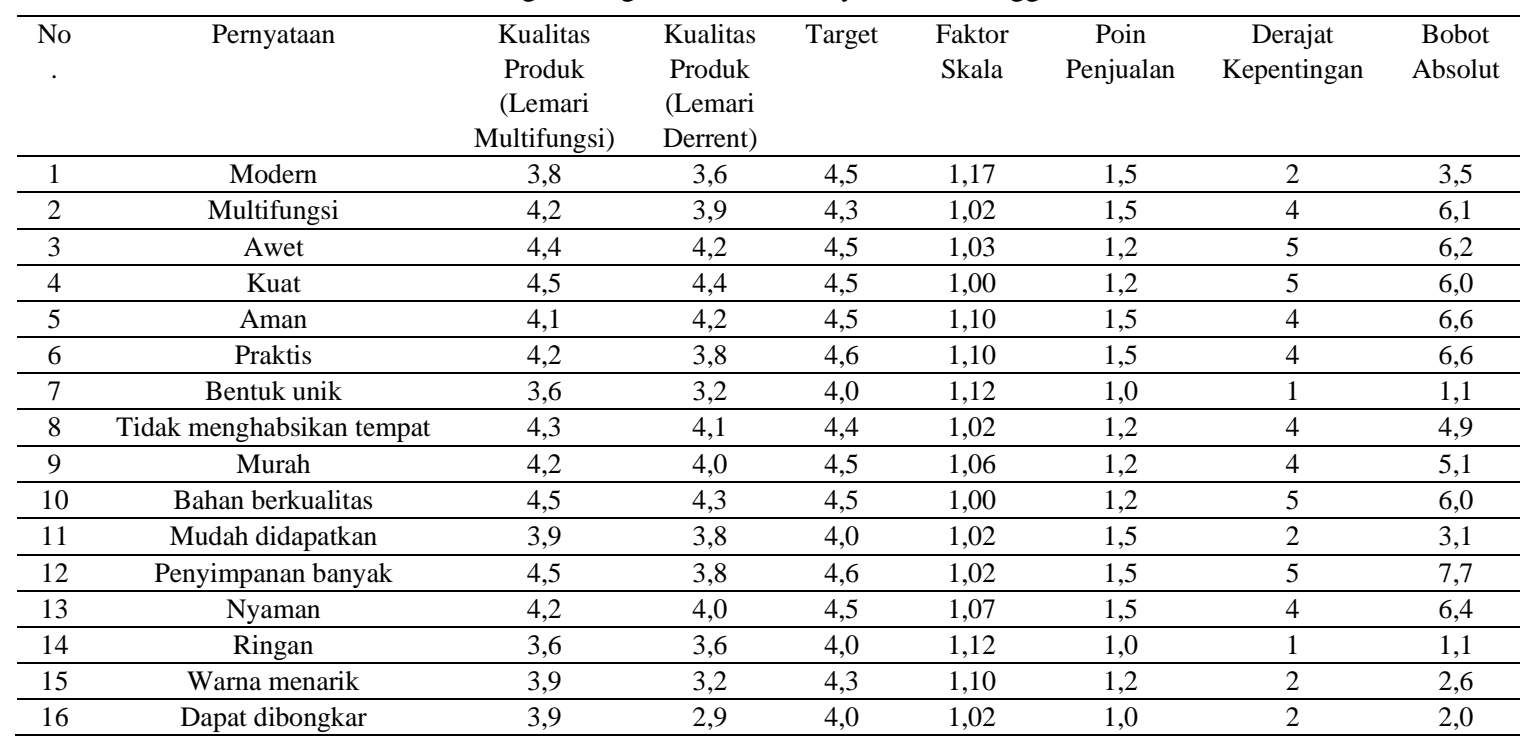

Tabel 3. Pengembangan Prioritas Deskripsi Secara Teknik

\begin{tabular}{|c|c|c|c|c|c|c|c|}
\hline No. & Pernyataan & $\begin{array}{c}\text { Kualitas } \\
\text { Produk (Lemari } \\
\text { Multifungsi) }\end{array}$ & $\begin{array}{l}\text { Kualitas Produk } \\
\text { (Lemarri Derrent) }\end{array}$ & $\begin{array}{c}\text { Derajat } \\
\text { Kepentingan }\end{array}$ & Target & $\begin{array}{c}\text { Bobot } \\
\text { Absolut }\end{array}$ & $\begin{array}{l}\text { Bobot } \\
\text { Relatif }\end{array}$ \\
\hline 1 & Jenis Bahan & 4,5 & 4,3 & 5 & 4,6 & 1,17 & 1,5 \\
\hline 2 & Keindahan Desain & 4,2 & 3,5 & 2 & 4,5 & 1,02 & 1,5 \\
\hline 3 & Biaya Produksi & 4,2 & 4,0 & 3 & 4,5 & 1,03 & 1,2 \\
\hline 4 & Model Produk & 4,2 & 4,0 & 3 & 4,5 & & \\
\hline 5 & Ergonomis & 4,2 & 4,0 & 3 & 4,3 & 1,00 & 1,2 \\
\hline 6 & Pemasaran & 3,9 & 3,8 & 1 & 4,5 & 1,10 & 1,5 \\
\hline
\end{tabular}

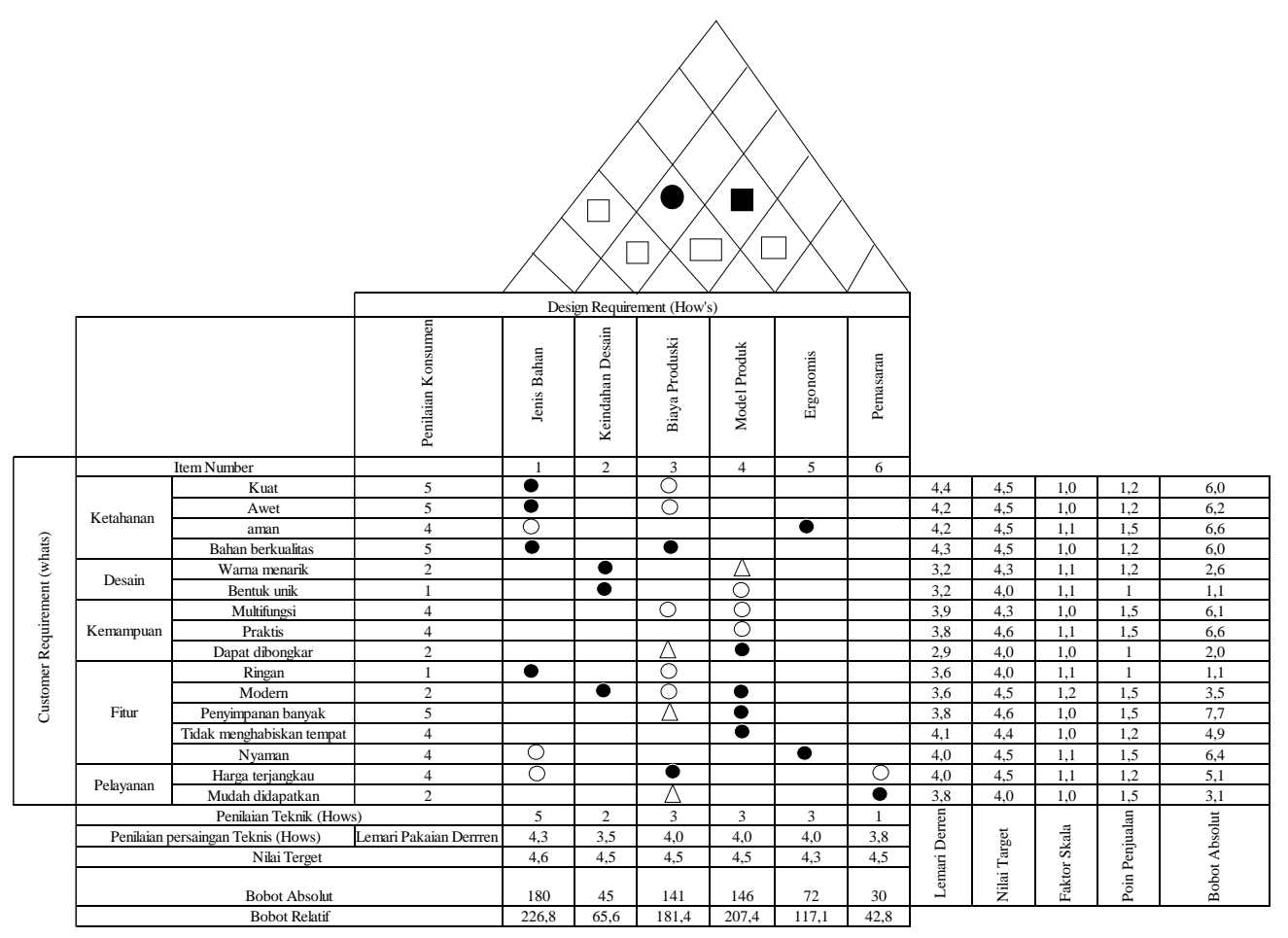

Gambar 5. Hasil QFD Lemari Pakaian dan Hija 
Rancangan produk lemari multifungsi dilakukan berdasarkan kebutuhan dan keinginan konsumen dalam QFD sehingga diperoleh hasil rancangan produk seperti pada gambar 6 dan gambar 7 .

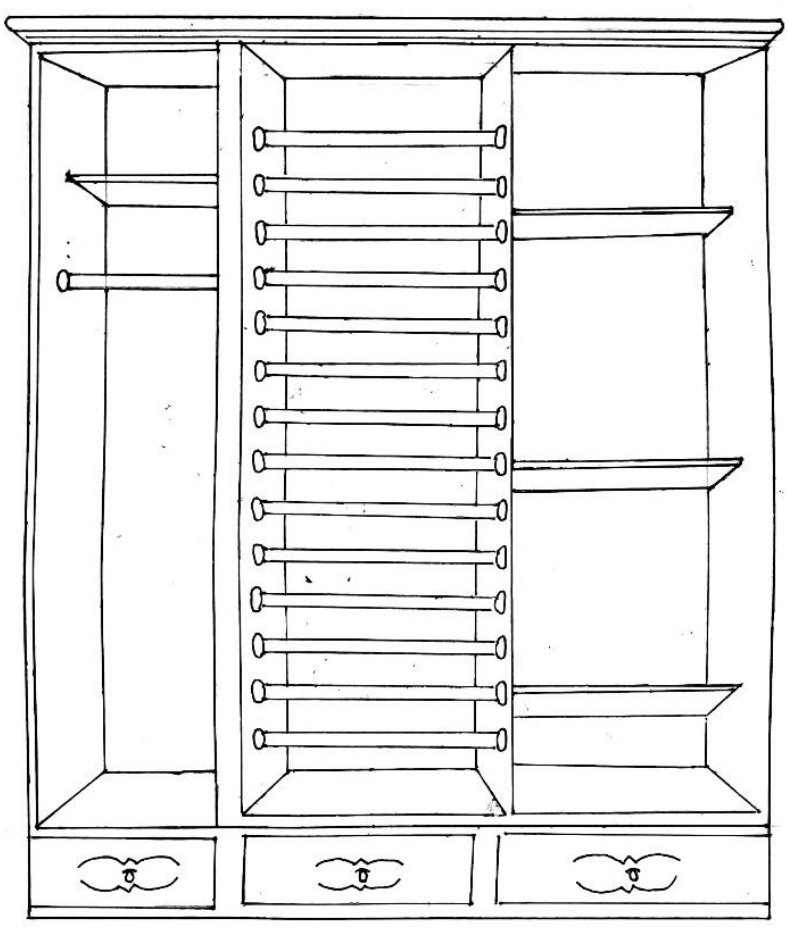

Gambar 6. Lemari Tampak Dalam

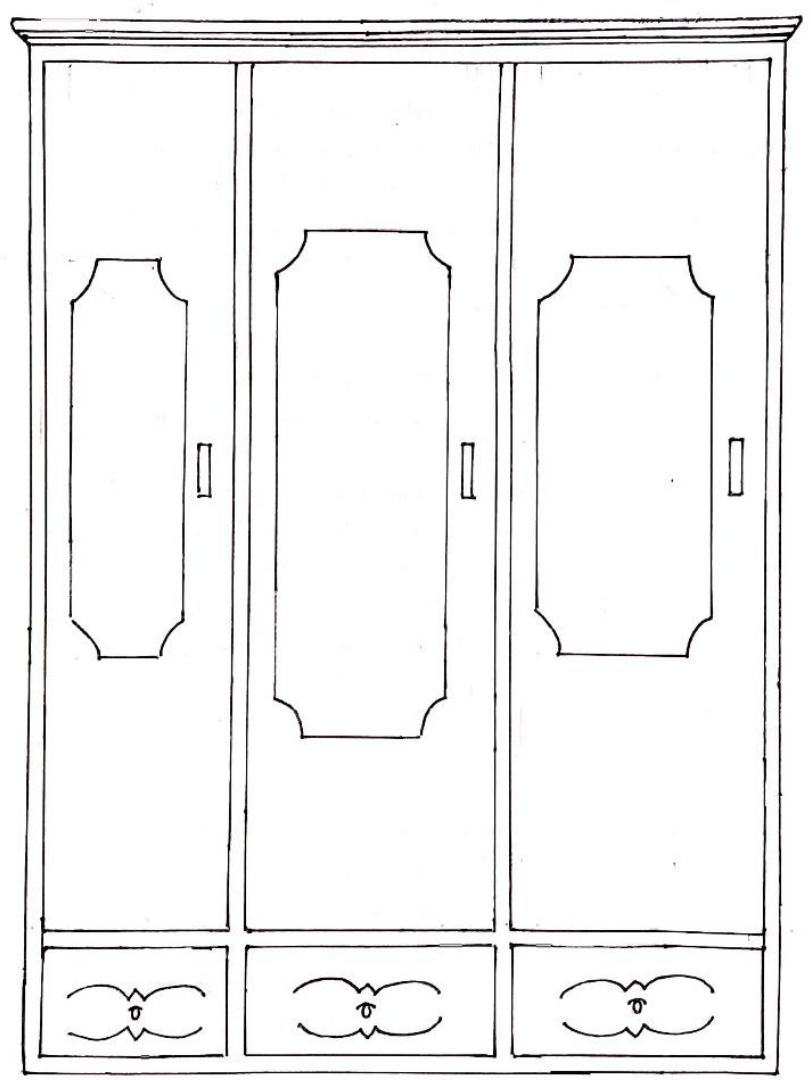

Gambar 7. Lemari Tampak Depan
Lemari multifungsi sudah dirancang sesuai dengan kebutuhan dan keinginan pelanggan sehingga lemari tersebut dapat menjadi sebuah jawaban dari kebutuhan dan keinginan masyarakat. Lemari tersebut dapat digunakan untuk menyimpan dan menggantung pakaian, menggantung hijab dan menyimpanan aksesories.

\subsection{Aspek Kajian Evaluasi Peluang Usaha}

Kajian evluasi peluang usaha dilakukan untuk mengetahui kelayakan usaha lemari pakian dan hijab dilakukan pengkajian terjadap tujuh aspek yaitu aspek yuridis, aspek teknis dan teknologi, aspek pasar dan pemasaran, aspek finansial, aspek organisasional, aspek persaingan, dan aspek kajian SKB (Amdal).

a. Aspek Yuridis

Bentuk badan usaha lemari multifungsi adalah perusahaan perseorangan dimana seluruh modal usaha lemari multifungsi berasal dari pemilik usaha. Pengelolaan usaha lemari multifungsi dikelola secara langsung oleh pemilik usaha. Seluruh keuntungan usaha lemari multifungsi dimilki secara utuh oleh pemilik usaha. Setiap resiko yang terjadi pada usaha lemari multifungsi menjadi tanggung jawab dari pemilik usaha.

Bidang usaha ini termasuk kedalam bidang usaha furniture khusunya pembuatan lemari multifungsi. Sistem pengupahan pada usaha ini adalah sistem harian.

Lokasi usaha lemari multifungsi berada di desa Balonggandu, kecamatan Jatisari. Pendirian lokasi usaha di daerah tersebut memerlukan izin pendirian usaha kepada pemerintah setempat agar tidak terjadi permasalahan di masa yang akan datang. Selain itu, pendirian usaha lemari multifungsi juga membutuhkan izin dari pemerintah sesuai dengan Peraturan Menteri Perdagangan Republik Indonesia Nomor 36/M-DAG/PER/2007taentang penerbitan surat izin usaha perdagangan yang disebut dengan SIUP adalah surat izin untuk dapat melaksanakan kegiatan usaha perdaganagan, yang selanjutnya disebut SIUP.

Bentuk dukungan yang diberikan oleh masyarakat terhadap usaha produk lemari multifungsi menjadi bukti bahwa fungsi dari lemari ini menjawab permasalahan yang ada di masyarakat. Adanya usaha lemari multifungsi diharapkan dapat menjadi usaha yang bermanfaat bagi masyarakat sekitar.

b. Aspek teknis dan teknologis

Kebutuhan lahan untuk pendirian usaha lemari multifungsi adalah $150 \mathrm{~m}^{2}$ yang berlokasi di Desa Balonggandu kcamatan Jatisari. Mesin yang diperlukan untuk produksi lemari multifungsi yaitu mesin 1 gergaji, 1 mesin amplas, 1 mesin bor, mesin 1 serut dan 1 mesin profil. 
Tenaga pekerja yang diperlukan untuk usaha lemari multifungsi adalah sebanyak 4 orang yang terdiri atas 1 orang pembuat rangka lemari, 1 orang bekerja dibagian pemotongan kayu, 1 orang dibagian assembly, 1 orang bekerja di bagian pengecatan. orang bekerja dibagian pemotongan kayu, 1 orang bekerja di bagian finishing.

Proses pengadaan bahan baku dan bahan pembantu untuk produksi lemari multifungsi dilakukan dengan cara melakukan pemesanan kepada supplier. Setelah melakukan pemesanan barang, pesanan akan dikirimkan ke tempat pembuatan lemari dalam beberapa hari.

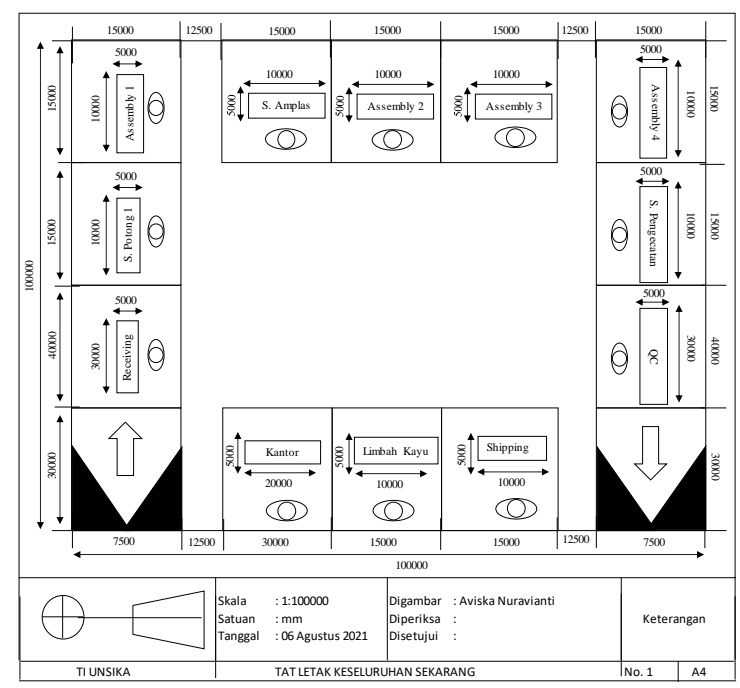

Gambar 8. Layout Usaha Lemari Multifungsi

Layout usulan untuk usaha lemari multifungsi terdiri atas ruang receiving yaitu untuk menerima seluruh bahan baku kayu dan bahan pembantu lainnya untuk produksi lemari, terdapat 1 stasiun potong yaitu untuk melakukan pemotongan kayu, 1 stasiun amplas untuk melakukan proses pengamplasan, 4 stasiun assembly yaitu untuk melakukan perakitan lemari multifungsi, 1 stasiun pengecetan untuk memberikan warna pada lemari, 1 stasiun quality control (QC), 1 ruangan shipping untuk menyimpan lemari yang sudah jadi dan siap untuk diantar ke pelanggan, 1 tempat penyimpanan limbah kayu yang akan dimanfaatkan kembali dan terdapat 1 ruangan kantor. limbah kayu yang akan dimanfaatkan kembali dan terdapat 1 ruangan kantor.

Proses produksi lemari multifungsi dilakukan melalui bebetrapa tahap yang dimulai dari bahan baku hingga menjadi barang jadi. Tahapan-tahapan pembuatan lemari multifungsi sebagai berikut:

1) Ukur kayu untuk membuat rangka lemari bagian samping yaitu $60 \mathrm{~cm} \times 200 \mathrm{~cm}$ sebanyak 4 buah untuk lemari multifungsi 4 pintu. Untuk bagian samping kiri, samping tengah dan 2 untuk bagian tengah. Bagian atas dan bawah lemari diukur dengan ukuran $180 \mathrm{~cm}$ x $60 \mathrm{~cm}$ sebanyak 2 buah. Bagian belakang lemari memiliki ukuran $180 \mathrm{~cm}$ x $200 \mathrm{~cm}$. Membuat bagian sekat antara lemari dan laci dengan ukuran untuk bagian kiri lemari $46 \times 60 \mathrm{~cm}$, bagian tengah 61 x $60 \mathrm{~cm}$ dan bagian samping kanan 461 x $60 \mathrm{~cm}$. Untuk membuat laci bagian kiri kayu diukur dengan ukuran $46 \mathrm{~cm}$ x $15 \mathrm{~cm}$, untuk bagian laci tengah dan samping kanan ukuran kayu yang diperlukan yaitu $61 \mathrm{~cm}$ x $15 \mathrm{~cm}$. Ukur sekat untuk bagian dalam lemari samping kiri dengan ukuran $46 \mathrm{~cm}$ x $60 \mathrm{~cm}$, untuk bagian kanan $61 \mathrm{x}$ $60 \mathrm{~cm}$. Ukuran pintu lemari bagaian kiri yaitu 46 x $196 \mathrm{~cm}$, samping kanan dan tengah adalah 61 $\mathrm{cm} \times 196 \mathrm{~cm}$.

2) Setelah dikur kayu dipotong di stasiun potong sesuai dengan ukuran yang telah ditentukan.

3) Kayu yang telah dipotong kemudian dirakit pada assembly 1 sehingga membentuk kerangka lemari dan laci lemari. Kemudian pasang sekat lemari sebagai tempat penyimpanan pakaian.

4) Haluskan permukaan rangka lemari, laci, pintu dan sekat lemari pada stasiun amplas.

5) Pada assembly 2, rakit gantungan hijab dan gantungan pakiaan dengan rangka lemari yang sudah dirakit sebelumnya.

6) Setelah itu rakit pintu lemari dengan rangka lemari di assembly 3.

7) Setelah itu rakit pintu lemari dengan rangka lemari di assembly 4

8) Setelah lemari terbentuk, kemudian dilakukan pengecatan lemari pada stasiun pengecatan agar lemari terlihat menarik.

9) Lemari kemudian dilakukan pengecekan kualitas untuk memastikan bahwa lemari yang diproduksi layak untuk dikirim kepada pelanggan.

10) Simpan lemari yang telah selesai dibuat kedalam ruang shipping yang kemudian akan dikirim kealamat pelanggan.

11) Aspek pasar dan pemasaran

c. Aspek Pasar dan Pemasaran

Segementasi pasar produk lemari pakaian dan hijab dibagi berdasarkan geografis, demografis dan psikografis. Segmen geografis dibagi berdasarkan masyarakat yang tinggal di kabupaten Karawang dan yang tinggal di luar kabupaten Karawang. Secara demografis segmen pasar dibagi berdasarkan jenis kelamin dan usia. Target pasar secara demografis dibagi menjadi segemen dengan usia dewasa yaitu 20 tahun sampai dengan 44 tahun dengan jenis kelamin perempuan. Lemari pakaian dan hijab dibuat dengan target pasar perempuan berhijab, tetapi dapat digunakan untuk perempuan yang tidak berhijab karena rak hijab yang ada di dalam lemari dapat dibongkar pasang. Pasar yang menjanjikan dapat memberikan kemudahan dalam melakukan penjualan produk kepada konsumen (Dwiputra, 2017). Berdasarkan psikografis usaha lemari pakaian dan hiijab membagi pasar berdasarkan gaya hidup, kelas sosial dan kepribadian. Produk lemari pakaian dan hijab dijual dibeberapa toko furniture yang ada di Karawang. Pemasaran produk lemari pakaian dan hijab dilakukan secara online agar dapat menjangkau masyarakat di luar kabupaten 
Karawang. Pemasaran produk lemari pakaian dan hijab menggunakan strategi marketing mix. Pendapat tersebut ditunjang oleh penelitian Silaningsih \& Utami (2018) yang menyatakan bahwa bauran pemasaran atau marketing mix adalah suatu strategi yang penting yang dilakukan oleh para pelaku usaha dalam melakukan pemasaran dalam kata lain bauran pemasaran menjadi suatu konsep aktivitas perusahaan atau usaha dalam mencapai tujuan perusahaan dengan mengefektifkan aktivitas pemasaran. Startegi marketing mix yang dilakukan dalam usaha lemari pakaian dan hijab yaitu marketing mix 4P. Strategi marketing mix 4P terdiri dari product, price, place dan promotion. Metode penetapan harga ditentukan berdasarkan biaya produksi dan pemasaran produk yang ditambah jumlah tertentu yang menutupi biaya langsung, overhead dan juga laba. Place atau distribusi penyaluran lemari pakaian dan hijab dilakukan dengan distribusi langsung yaitu dari produsen langsung ke konsumen dan distribusi tidak langsung produsen ke pedagang besar lalu ke konsumen. Promosi yang dilakukan usaha lemari pakain dan hijab meliputi peamasangan papan nama di depan tempat produksi yang bertujuan agar setiap orang yang melewati tempat produksi dapat membaca dan mengetahui usaha tersebut. Selain pemasangan papan nama, dilakukan personal selling dan sales promotion. Personal selling dilakukan dengan bertemu langsung oleh calon pembeli dan memberitahu keunggulan produk. Sales promotion dilakukan dengan cara memberikan contoh gambar dari model produk yang dijual. Rata-rata penjualan produk dengan metode peramalan pada tahun ke satu sebanyak 34 produk lemari, tahun kedua 50 produk lemari, tahun ketiga 51 produk lemari, tahun keempat 61 produk lemari dan tahun kelima 91.

d. Aspek Finansial

Investi awal untuk usaha lemari pakaian dan hijab adalah pembelian mesin untuk proses produksi lemari pakaian dan hijab serta membeli mobil sebagai alat transportasi pengiriman lemari pakaian dan hijab. Aspek finansial dalam keuangan menjelaskan usaha yang sehat yaitu usaha yang dapat memberikan keuntungan yang layak serta dapat memenuhi kewajiban finansial. Aspek finansial menghitung perkiraan biaya yang digunakan untuk modal awal dan pengadaan harta tetap usaha (Nainggolan, 2017). Biaya investasi usaha lemari pakaian dan hijab sebesar Rp. 101.310.000 yang dialokasikan untuk membeli mesin amplas dengan harga Rp. 210.000, gergaji mesin dengan harga Rp. 300.000, mesin serut dengan harga Rp. 255.000, mesin profil dengan harga Rp. 310.000, mesin bor dengan harga Rp. 235.000 dan mobil pickup dengan harga Rp. 100.000.0000. Biaya penyusutan sebesar Rp. 796.650. Selain biaya investasi awal dalam pembuatan lemari pakaian dan hijab diperlukan biaya bahan baku yang terdiri dari biaya untuk pembelian kayu. Biaya bahan baku yang digunakan dalam pembuatan lemari pakaian dan hijab sebanyak 5 buah lemari menghabiskan biaya sebesar Rp. 12.097.500

Tabel 4. Biaya Bahan Baku

\begin{tabular}{cccc}
\hline No & $\begin{array}{c}\text { Komponen } \\
\text { Biaya }\end{array}$ & Jumlah & Harga \\
\hline 1 & Kayu Meranti & 30 Lembar & Rp. 11.100.000 \\
2 & Kayu Silinder & 105 Batang & Rp. 12.097.500 \\
\hline
\end{tabular}

Biaya bahan penolong adalah bahan-bahan yang digunakan dalam pembuatan lemari pakaian dan hijab. Bahan tersebut merupakan bahan yang membantu proses produksi lemari pakaian dan hijab. Bahan penolong untuk memproduksi lemari multifungsi terdiri dari 11 item jenis bahan. Bahanbahan penolong tersebut dapat dilihat pada tabel 5 berikut

Tabel 5. Biaya Bahan Penolong

\begin{tabular}{|c|c|c|c|}
\hline No. & Komponen Biaya & Jumlah & Harga \\
\hline 1 & Amplas & 15 Lembar & Rp. 525.000 \\
\hline 2 & Dempul & $10 \mathrm{Kg}$ & Rp. 300.000 \\
\hline 3 & Cat & $10 \mathrm{Kg}$ & Rp. 650.000 \\
\hline 4 & Tiner & $10 \mathrm{Kg}$ & Rp. 210.000 \\
\hline 5 & Lem & $10 \mathrm{Kg}$ & Rp. 120.000 \\
\hline 6 & Paku & $5 \mathrm{Kg}$ & Rp. 75.000 \\
\hline 7 & Handle Pintu & 30 Buah & Rp. 450.000 \\
\hline 8 & Engsel & 15 Pasang & Rp. 210.000 \\
\hline 9 & Handle Laci & 15 Buah & Rp. 202.500 \\
\hline 10 & Clear & 8 Kaleng & Rp. 520.000 \\
\hline 11 & Kunci Lemari & 15 Buah & Rp. 225.000 \\
\hline Total & & & Rp. 3.487.500 \\
\hline
\end{tabular}

Untuk menentukan harga pokok penjualan dilakukan perhitungan pada biaya bahan baku, overhead, biaya tenaga kerja langsung, dan biaya non produksi. Harga jual diperoleh dari harga pokok penjualan ditambah margin keuntungan $30 \%$.

Tabel 6. Penentuan HPP

\begin{tabular}{lll}
\hline No & Komponen Biaya & Jumlah \\
\hline 1 & Biaya Bahan Baku & Rp. 12. 097.500 \\
\hline 2 & Biaya Tenaga Kerja Langsung & Rp. 75.000 \\
\hline 3 & Biaya Overhead & Rp. 4.407.150 \\
\hline 4 & Biaya Non Produksi & Rp. 150.000 \\
\hline Total & Rp. 16.729.650 \\
\hline
\end{tabular}

Biaya non produksi adalah biaya pengiriman lemari pakaian dan hijab. Biaya tenaga kerja langsung dibebankan untuk membayar upah karyawan dalam satu hari. Biaya overhead meliputi biaya bahan penolong, biaya depresiasi dan biaya listrik. Biaya listrik untuk membuat 5 lemari adalah Rp. 150.000 .

HPP unit satu produk lemari adalah Rp. 3.345.930 dan untuk menentukan harga jual yaitu harga pokok produksi ditambah laba sebesar $30 \%$ sehingga harga jual satu buah lemari pakain dan hijab Rp. 4.349.709 atau Rp. 4.350.000. BEP unit produk lemari pakaian dan hijab adalah 1 unit. Untuk BEP rupiah diperoleh Rp. 3. 132.334. Untuk menghitung laba rugi setiap tahun maka dihitung 
biaya penjualan produk sesuai dengan harga pokok produksi, hasil penjualan, biaya operasional, dan biaya untuk membayar pajak. Kriteria untuk penilaian investasi menggunakan metode payback period (PP), net present value (NPV), internal rate of return (IRR), profitability index (PI), dan benefit cost ratio $(\mathrm{B} / \mathrm{C})$.

Tabel 7. Analisa Kelayakan Usaha

\begin{tabular}{|c|c|c|c|}
\hline No & Analisis & $\begin{array}{c}\text { Hasil } \\
\text { Analisis }\end{array}$ & Keterangan \\
\hline 1 & Payback Period & $\begin{array}{ll}4 \text { Tahun } 1 \\
\text { Bulan }\end{array}$ & Layak \\
\hline 2 & Net Present Value & 132.826 .539 & Layak \\
\hline 3 & Internal Rate of Return & $38 \%$ & Layak \\
\hline 4 & Profitability Index & 2,3 & Layak \\
\hline 5 & Benefit Cost Ratio & 1,3 & Layak \\
\hline
\end{tabular}

Untuk megetahui jika terjadi perubahanperubahan parameter-parameter produksi untuk mendapatkan keuntungan dilakukan analisis sensitivitas. Analisis sensitivitas adalah suatu cara yang digunakan untuk mengetahui kelayakan usaha apabila terdapat perubahan-perubahan dalam aspek finansialnya. Analisis sensitivitas bertujuan untuk untuk menilai apa yang terjadi pada analsisi kelayakan usaha di dalam perhitungan biaya atau manfaat (Nauli, Yusmini \& Edwina, 2018). Analisis sensitivitas dihitung dengan dua skenario yaitu kenaikan harga bahan baku sebesar 4\% dan penurunan penerimaan sebesar $10 \%$. Harga input yang mengalami perubahan dalam analisis sensitivitas adalah kenaikan harga bahan baku utama yaitu kayu dengan kenaikan sebesar 4\%. Apabila terjadi kenaikan harga bahan baku utama akan sangat berpengaruh pada benefit yang diperoleh pada usaha lemari pakaian dan hijab. Analisis kelayakan usaha dengan kenaikan harga bahan baku sebesar 4\% diperoleh PP 4 tahun 6 bulan, NPV sebesar 84.089.520, IRR sebesar 29\%, PI 1,8 dan $\mathrm{B} / \mathrm{C}$ ratio sebesar 1,26. Apabila terjadi kenaikan harga bahan baku utama yaitu kayu sebesar $4 \%$ usaha lemari pakaian dan hijab masih tetap mendapatkan keuntungan. Anslisis kelayakan sensitivitas dengan penurunan kuantitas produksi sebesar $10 \%$ dalam 5 tahun memperoleh PP sebesar 4 tahun 5 bulan, NPV sebesar 83.239.429, IRR sebesar $28 \%$, PI sebesar 1,8 dan $\mathrm{B} / \mathrm{C}$ ratio 1,30 . Setelah dilakukan analisis sensitivitas terhadap penurunan pada skala produksi sebesar $10 \%$ dengan harga jual yang tetap usaha lemari pakaian dan hijab masih layak untuk dijalankan. Karena masih tetap memperoleh keuntungan. Jika terdapat penuruan kuantitas produksi dibawah $10 \%$ usaha lemari pakaian dan hijab masih tetap mendapatkan keuntungan.

e. Aspek Organisasional

Kebutuhan sumber daya manusia menjadi aspek dalam manajemen operasi yang harus direncanakan ketika memulai usaha (Kristiana \& Lawrence, 2019). Struktur organisasi usaha lemari pakaian dan hijab disusun dengan sederhana dengan pemilik usaha berada pada posisi atas. Pada usaha lemari pakian dan hijab hanya terdiri dari satu divisi yaitu divisi produksi yang bertugas dalam pembuatan lemari pakaian dan hijab. Pemilik usaha lemari pakian dan hijab bertanggung jawab terhadap pengambilan keputusan yang terkait dengan usaha lemari pakaian dan hijab. Jumlah tenaga kerja yang sedikit menyebabkan hubungan antara pemilik usaha dengan tenaga kerja yang bersifat kekeluargaan dan tingkat spesialisasi yang belum tinggi. Karyawan pada usaha lemari pakian dan hijab berada di bagian produksi karena pada bagian produksi yang banyak membutuhkan karyawan. Jumlah tenaga untuk usaha pakaian dan hijab adalah 2 orang pada bagian produksi dengan kualifikasi minimal pendidikan SMA. Sistem pengupahan karyawan karyawan dihitung perhari dengan upah Rp. 75.000 untuk 2 orang karyawan. Analisis organisasi menunjukkan pemilik usaha telah menjalankan fungsi manajemen dengan baik. Struktur organisasi yang sederhana memudahkan dalam menjalankan tugas dan tanggung jawab di setiap bagian.

f. Analisis Persaingan

Perusahaan harus mampu berkompetisi dengan pesaing agar dapat bertahan dan tetap menjadi pilihan utama para konsumen (Pratama, Dewi, \& Baroto, 2015). Beberapa kelebihan yang dimiliki pesaing produk lemari pakaian dan hijab yaitu harga produk pesaing yang lebih murah namun model yang kurang modern, model lemari dengan dua pintu dan satu pintu kurang dapat menampung pakaian maupun hijab yang banyak. Strategi yang diterapkan dalam usaha lemari pakian dan hijab adalah strategi yang difokuskan pada segmentasi pada usaha lemari pakaian dan hijab. Berdasarkan anlisis lingkungan internal dan eksternal usaha lemari pakaian dan hijab memiliki kelemahan dan kekuatan. Kekuatan usaha lemari pakaian dan hijab adalah kualitas produk lemari yang berkualitas, pelayanan terhadap konsumen yang baik, kapasitas lemari yang besar terdiri dari tiga pintu dan memiliki jaminan kualitas terhadap konsumen. Selain kekuatan yang dimiliki terdapat kelemahan dari usaha lemari pakaian dan hijab adalah harga yang sedikit lebih mahal. Pada bagian lingkungan eksternal usaha lemari pakain dan hijab memiliki peluang yaitu banyaknya para pengguna hijab yang membutuhkan tempat untuk menyimpan hijab dan perkembangan e-commerce yang meningkat. Ancaman dalam usaha lemari pakian dan hijab adalah persaingan yang tinggi dengan produk yang sejenis. Akan tetapi usaha lemarai pakaian dan hijab memiliki rencana yang jelas dan bergerak cepat dalam memonitor 
perkembangan dengan mengikuti model terkini yang ada dipasaran sehingga dapat bersaing dengan industri yang sejenis industri lemari dan layanannya.

g. Aspek Kajian SKB (Amdal)

Tujuan analisis terhadap aspek lingkungan adalah mengetahui dampak yang ditimbulkan terhadap lingkungan, dampak positif dan negatif. Proses produksi lemari pakaian dan hijab yang positif adalah dapat membuka lapangan pekerjaan baru jika usaha lemari pakian dan hijab semakin berkembang kedepannya. Dampak negatif dari usaha lemari pakaian dan hijab yaitu menghasilkan limbah yaitu serbuk atau serpihan kayu. Bahan baku kayu dalam pembuatan lemari pakaian dan hijab tidak murah terurai jika hanya dibuang atau ditimbun pada suatu tempat. Sehingga diperlukan pemanfaatan pada limbah serpihan kayu yang dapat memiliki manfaat yaitu dengan pembuatan arang dari serpihan kayu.

\section{Kesimpulan}

Kebutuhan dan keinginan pelanggan terhadap lemari multifungsi yaitu kaut, awet, aman, bahan berkualitas, warna menarik, bentuk unik, multifungsi, praktis, dapat dibongkar, ringan, modern, penyimpanan banyak, tidak menghabiskan tempat, nyaman, harga terjangkau dan mudah didapatkan. Atribut kebutuhan dan keinginan pelanggan terhadap produk lemari multifungsi yang memiliki nilai terbesar yaitu penyimpanan banyak, aman, praktis, harga terjangkau, awet, multifungsi, kuat, bahan berkualitas, harga terjangkau, tidak menghabiskan tempat, modern, mudah didapatkan, warna menarik, dapat dibongkar, bentuk unik dan ringan. Berdasarkan analisis QFD karakteristik teknik yang memiliki nilai tertinggi yang menentukan prioritas terhadap pengembangan produk yaitu jenis bahan, model produk, biaya produksi, ergonomis, keindahan desain dan pemasaran.

Setelah dilakukan kajian evaluasi peluang usaha terhadap tujuh aspek yaitu aspek yuridis, aspek teknis dan teknologi, aspek pasar dan pemasaran, aspek finansial, aspek organisasional, aspek persaingan dan aspek AMDAL dapat disimpulkan bahwa usaha lemari multifungsi layak untuk dijalankan.

\section{Daftar Pustaka}

Afiyah, A., Saifi, M., \& Dwiatmanto. (2015). ANALISIS STUDI KELAYAKAN USAHA PENDIRIAN HOME INDUSTRY (Studi Kasus pada Home Industry Cokelat âCozyâ Kademangan Blitar). Jurnal Administrasi Usaha S1 Universitas Brawijaya, Vol. 23, No.1, hal. 1-11.

Anggraeni, M., Desrianty, A., \& Yuniar. (2013). Rancangan Meja Dapur Multifungsi Menggunakan Quality Function Deployment (QFD). Reka Integra, Vol. 1, No. 2, hal. 159-169.
Silaningsih, E., \& Utami, P. (2018). PENGARUH MARKETING MIX TERHADAP MINAT BELI KONSUMEN PADA USAHA MIKRO KECIL DAN MENENGAH (UMKM) PRODUK OLAHAN MAKANAN RINGAN. Jurnal Sosial Humaniora, Vol. 9, No. 2, hal. 144-158.

Faradiba, B \& Musmulyadi. (2020). ANALISI STUDI KELAYAKAN BISNIS USAHA WARALABA DAN CITRA MEREK TERHADAP KEPUTUSAN PEMBELIAN "ALPOKATKOCOK_DOUBIG" DI MAKASSAR. Jurnal Keuangan dan Perbankan, Vol. 2, No. 2, hal 52-61.

Dwiputra, G. A. (2017). Analisis Kelayakan Pengembangan Usaha Rumah Makan Krebo Jantan. Jurnal Sistem dan Manajemen Industri, Vol. 1, No. 2, hal 85-90.

Nauli, I. M., Yusmini., \& Edwina, S. (2018). Analisis Kelayakan Finansial Usaha Franchise O'chicken di Kelurahan Simpang Tiga Kecamatan Bukit Raya Kota Pekanbaru. Jurnal Agribsnis, Vol 20, No, 2, hal. 1169-180.

Kristian, W., \& Indrawan, F. (2019). Studi Kelayakan Bisnis dalam Rangka Pendirian XX Café. Jurnal Akauntansi Maranatha, Vol. 11, No. 2, hal 379. 400.

Kristiana, Y., \& Lawrence, J. (2019). Analisis Kelayakan Bisnis Water Park di Pulau Bintan . Jurnal Manajemen, Vol. 14, No. 2, hal 239-256.

Trenggonowati, D. L. (2017). Metode Pengembangan Produk QFD untuk Meningkatkan Daya Saing Perusahaan. Jurnal Spektrum Industri. Vol. 15, No. 1, hal. 1-18.

Nainggolan, O. V. B. (2017). Analisis Kelayakan Usaha Mikro Kecil dan Menengah (UMKM) Sepatu DAN Sandal di Bogor. Jurnal Bina Akuntansi, Vol 4, No. 2, hal 101-149.

Gunawan, K. (2018). Peran Studi Kelayakan Bisnis Dalam Peningkatan UMKM (Studi Kasus UMKM di Kabupaten Kudus). Jurnal Usaha, Vol. 6, No. 2, hal. 101-115.

Pratama, N. B., Dewi, S. K., \& Baroto, T. (2015). Analisis Persaingan Dan Kepuasan Konsumen Dengan Menggunakan Metode Correspondance Analysis Dan Importance Performance Analysis. Jurnal Teknik Industri, Vol. 16, No. 2, hal 74-82.

Shofa, M. J., \& Iman, F. (2020). Pengembangan Produk Spring Steel Menggunakan Kerangka Kerja Quality Function Deployment ( QFD ). Jurnal Performa: Media Ilmiah Teknik Industri, Vol. 19, No. 1, hal 9-18. 